LEARNING TO READ:

AN INTEGRATED VIEW FROM RESEARCH AND PRACTICE 


\section{NEUROPSYCHOLOGY AND COGNITION}

\section{VOLUME 17}

Series Editor:

R. Malatesha Joshi, Oklahoma State University, U.S.A.

Advisory Board:

Alfonso Caramazza, The Johns Hopkins University, U.S.A.

George Hynd, University of Georgia, U.S.A.

C.K. Leong, University of Saskatchewan, Canada

John Marshall, University of Oxford, U.K.

Gabriele Miceli, Università Cattolica Del Sacro Cuore, Italy

Loraine Obler, City University of New York, U.S.A.

Sandra Witelson, McMaster University, Canada

The purpose of the Neuropsychology and Cognition series is to bring out volumes that promote understanding in topics relating brain and behavior. It is intended for use by both clinicians and research scientists in the fields of neuropsychology, cognitive psychology, psycholinguistics, speech and hearing, as well as education. Examples of topics to be covered in the series would relate to memory, language acquisition and breakdown, reading, attention, developing and aging brain. By addressing the theoretical, empirical, and applied aspects of brain-behavior relationships, this series will try to present the information in the fields of neuropsychology and cognition in a coherent manner.

The titles published in this series are listed at the end of this volume. 


\title{
LEARNING TO READ: AN INTEGRATED VIEW FROM RESEARCH AND PRACTICE
}

\author{
Edited by \\ TEREZINHA NUNES \\ Child Development \& Learning. \\ Institute of Education. \\ University of London, U.K.
}

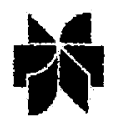

SPRINGER-SCIENCE+BUSINESS MEDIA, B.V. 
Library of Congress Cataloging-in-Publication Data.

ISBN 978-0-7923-5992-0 ISBN 978-94-011-4826-9 (eBook)

DOI 10.1007/978-94-011-4826-9

Printed on acid-free paper

All Rights Reserved

(c) 1999 Springer Science+Business Media Dordrecht Originally published by Kluwer Academic Publishers in 1999

Softcover reprint of the hardcover 1st edition 1999

No part of the material protected by this copyright notice may be reproduced or utilized in any form or by any means, electronic or mechanical, including photocopying, recording or by any information storage and retrieval system, without written permission from the copyright owner. 


\section{TABLE OF CONTENTS}

List of Contributors

About This Book $\quad$ xi

Section 1:

Developmental Research and

the Teaching of Reading

TEREZINHA NUNES

Introductory Comments

PETER BRYANT, TEREZINHA NUNES and MIRIAM BINDMAN

Morphemes and Spelling

MICHEL FAYOL, MARIE GENEVIÈVE THEVENIN, JEAN PIERRE JAROUSSE and CORINNE TOTEREAU

From Learning to Teaching to Learning French Written Morphology

EMILIA FERREIRO

Oral and Written Words. Are They the Same Units?

IRIS LEVIN, DORIT RAVID and SHARON RAPAPORT

Developing Morphological Awareness and Learning to Write:

A Two-Way Street

MORAG STUART, JACKIE MASTERSON, MAUREEN DIXON and PHILIP QUINLAN

Interacting Processes in the Development of Printed Word Recognition

Section 2:

Assessment and Intervention for

Children with Reading Difficulties

TEREZINHA NUNES

Introductory Comments 
DORTHE KLINT PETERSEN and CARSTEN ELBRO

Pre-school Prediction and Prevention of Dyslexia:

A Longitudinal Study with Children of Dyslexic Parents

TEREZINHA NUNES and ATHANASIOS AIDINIS

A Closer Look at the Spelling of Children with Reading Problems

BENTE E. HAGTVET

Egoinvolved Stimulation of Early Literacy

MARGARET SNOWLING, KATE NATION and VALERIE MUTER

The Role of Semantic and Phonological Skills in Learning to

Read: Implications for Assessment and Teaching

Section 3:

The Use of Theories by

Teachers and Teacher Educators

TEREZINHA NUNES

Introductory Comments

JENI RILEY

The Reading Debate

ANA TEBEROSKI

The Teaching-Learning Process in Early Written Language Acquisition

ANNE-MARIE CHARTIER

Theoretical Discussions and Pedagogical Practice:

How "Theorization" Can Help in Teacher Training

SIDNEY STRAUSS, DORIT RAVID, HANNA ZELCER and DAVID C. BERLINER

Relations between Teachers' Subject Matter Knowledge about Written Language and Their Mental Models about Children's Learning 


\section{Section 4:}

Issues in the Teaching and Assessment

of Children's Literacy Process

\section{TEREZINHA NUNES}

Introductory Comments

JANE HURRY, KATHY SYLVA and JENI RILEY

Focused Literacy Teaching at the Start of School

HANS BRÜGELMANN

From Invention to Convention. Children's Different Routes to

Literacy

ESTHER GEVA

Issues in the Development of Second Language Reading:

Implications for Instruction and Assessment

ALEXANDER MCMILLAN

Words, Letters and Smurphs: Apostrophes and Their Uses 


\section{LIST OF CONTRIBUTORS}

A. AIDINIS, Department of Child Development and Learning, Institute of Education, London, U.K.

D.C. BERLINER, Arizona State University, U.S.A.

M. BINDMAN, Department of Child Development and Learning, Institute of Education, London, U.K.

H. BRÜGELMANN, Universitäts-Gesamthochschule, Siegen, Germany

P. BRYANT, Department of Experimental Psychology, Oxford, U.K.

A.-M. CHARTIER, Service d'Histoire de l'Education, INRP, France

M. DIXON, Department of Psychology, University of Greenwich, London, U.K.

C. ELBRO, Department of General and Applied Linguistics, University of Copenhagen, Copenhagen, Denmark

M. FAYOL, L.E.A.D./C.N.R.S., Faculté des Sciences, Université de Bourgogne, Dijon, France

E. FERREIRO, CINVESTAV, Mexico City, Mexico

E. GEVA, The Ontario Institute for Studies in Education, University of Toronto, Canada

B.E. HAGTVET, Institute of Special Needs Education, University of Oslo, Blindern, Norway

J. HURRY, Institute of Education, CDU, University of London, U.K.

J.P. JAROUSSE, I.R.E.D.U./C.N.R.S., Faculté des Sciences, Université de Bourgogne, Dijon, France 
D. KLINT PETERSEN, Department of General and Applied Linguistics, University of Copenhagen, Copenhagen, Denmark

I. LEVIN, School of Education, Tel Aviv University, Israel

J. MASTERSON, University of Essex, U.K.

A. McMILLAN, Instituto do Magistério Primário, Quelimane, Zambezia, Mosambique

V. MUTER, University of York, U.K.

K. NATION, University of York, U.K.

T. NUNES, Department of Child Development and Learning, Institute of Education, London, U.K.

P. QUINLAN, University of York, U.K.

S. RAPAPORT, School of Education, Tel Aviv University, Israel

D. RAVID, School of Education, Tel Aviv University, Israel

J. RILEY, Primary Education, Institute of Education, University of London, U.K.

M. SNOWLING, University of York, U.K.

S. STRAUSS, Tel Aviv University, Israel

M. STUART, Psychology of Special Needs Education, Institute of Education, London, U.K.

K. SYLVA, Department of Education, University of Oxford, U.K.

A. TEBEROSKY, University of Barcelona, Spain

M.G. THEVENIN, I.R.E.D.U./C.N.R.S., Faculté des Sciences, Université de Bourgogne, Dijon, France

C. TOTEREAU, L.E.A.D./C.N.R.S., Faculté des Sciences, Université de Bourgogne, Dijon, France

H. ZELCER, Tel Aviv University, Israel 


\section{ABOUT THIS BOOK}

This book is the result of the joint effort of all the collaborators in two moments. First, we agreed to meet and discuss research and practice on literacy teaching and learning. Our commitment was to find out about questions that came both from theory and practice, to identify issues for further investigation, and to discuss options available to teachers and children in their joint effort of getting the children to become independent and competent readers and writers. With the support of the ESRC, the Nuffield Foundation, the British Council, and the Child Development and Learning Group of the Institute of Education (University of London), and thanks to Kim Vernon's superb organization, we had a fruitful meeting, where we considered each other's ideas and questions. The second moment was the production of this book. The papers included here are not simply a repetition of what each collaborator said in the meeting. They bear the mark of the issues and concerns raised during the meeting. As the editor, I am thankful to the authors, who made every effort to address a mixed group of researchers and teachers. Our meeting had shown us many differences between the two groups. For example, researchers have the licence to be interested in only one aspect of children's literacy at a time, or even throughout their own lives, but teachers do not: their children must conquer all of literacy. In contrast, teachers have the liberty to mix and match, to teach in this and that way over the course of the year or even the course of a day, but researchers need to be able to separate the effects of one form of teaching from that of another in their intervention studies, as well as analyse the consequences of combining methods.

The dialogue between these two perspectives is bound to be tense at times but is productive on every occasion. Researchers can become excited about their findings and forget other aspects of literacy. Teachers are used to the caution of considering established good practice and will not readily abandon an aspect of teaching simply because it is not the focus of a research project. But it is easy for both groups to slip into the security of established teaching and research practices and any meeting between these two groups can be a reminder that our answers are at best partial truths: we do not know all that there is to be known about literacy.

This book is a demonstration of how new ideas can lead to the reassessment of established practices and how the latter can in turn lead researchers to investigate other aspects of literacy which they may have ignored in the past. 
The book is organized in four sections. The first section is a collection studies on the development of reading and spelling which bring together questions about how children learn and how literacy should be taught. The second section concentrates on children who find the acquisition of literacy particularly difficult. The third considers how teachers and teacher educators use theories about literacy acquisition. The final section considers questions related to the assessment of children's progress in literacy and the design of literacy instruction. Each section is preceded by a brief introduction that pulls out some of the main issues across the chapters.

TEREZINHA NUNES 